\title{
Introduction: Reflection on/as Supplement
}

\author{
Ben Golder ${ }^{1}$. Sara Ramshaw ${ }^{2}$
}

Accepted: 2 June 2021 / Published online: 22 July 2021

(c) The Author(s), under exclusive licence to Springer Nature B.V. 2021

Peter Fitzpatrick was one of the most influential and revered of legal theorists in the English-speaking world. Best known for his work, The Mythology of Modern Law (1992), and his book, Modernism and the Grounds of Law (2001), Peter's written work spanned and influenced the fields not just of critical legal theory but also of law and colonialism, law and anthropology, postcolonial legal studies, law and society, law and the humanities, international law, and countless other disciplines and sub-disciplines of legal study. His non-written work, his supervision and mentoring of junior scholars and Ph.D. students and his creation of intellectual communities from Queensland to Kent to London and across the world, was and will remain legendary - and attests not only to the intellectual influence of his scholarship but to the special qualities of the man who produced it.

For this special issue, we invited scholars, both established and early career, to reflect on Peter's scholarship and legacy. In his edited collection entitled Dangerous Supplements: Resistance and Renewal in Jurisprudence (1991), Peter gathered preeminent legal scholars, such as Carol Smart, David Sugarman, Peter Goodrich, among others, to provide a critical supplement to (positivist) jurisprudence, ever attentive to its dual nature: exhibiting a responsive "elasticity" and "a capacity for self-renewal", while retaining a determinate "core of certainty" despite the wide variation in areas on the penumbra' (1991, p. 1). For Peter, '[t]he supplement provides what is lacking. It serves to complement and to complete that which is supplemented' (ibid.). Yet, he warns that to supplement is also to make certain 'that valuable things are kept on board' (ibid.).

In this vein, the articles gathered in this special issue are, in a sense, supplemental to Peter's oeuvre in that they are all engaging with his scholarship in new and exciting ways. However, they are not supplemental in the Derridian sense as being 'dangerous' or 'challenging the completeness and the adequacy of that which is

Ben Golder

b.golder@unsw.edu.au

Sara Ramshaw

sararamshaw@uvic.ca

1 Faculty of Law and Justice, University of New South Wales, Sydney, NSW 2052, Australia

2 Faculty of Law, University of Victoria, Victoria, BC, Canada 
within' (1991, pp. 1-2). Instead, they represent a supplementary engagement that is 'open, responsive' - and always 'unachieved' (p. 28). They offer students and readers of Peter's scholarship 'some introduction to areas of knowledge which have been of great significance intellectually [to him]' (p. 28), but which have not yet been explored fully in relation to Peter's work before now.

The issue begins with social anthropologist Melissa Demian offering a close reading of Peter's early work, Law and the State in Papua New Guinea (1980). Drawing on twenty years of her own research into the decolonising process in Papua New Guinea, she attempts to complete the meditation begun by Fitzpatrick during his period of residence in the country (1972-1975) as it transitioned to independence, but in doing so she draws out and emphasises the many ways in which Peter's work prefigured and anticipated many developments in non-state law-making.

In 'How to Make Concrete Laws out of Thin Air', James Martel offers a unique interpretation of how the law bridges the gap between its own non-being and its power in the world through Peter's scholarship. He focuses on how there are certain patterns and repetitions in the emergence of modern law and how the tension between non-being and being is never fully resolved, sometimes leading to, according to Martel, radical and, from the perspective of the powers that rule and enforce the law, undesirable outcomes.

Also engaging with Fitzpatrick's The Mythology of Modern Law in the context of recent cases relating to development in the Athabasca tar sands region in Canada, Sahar Shah brings Fitzpatrick into conversation with contemporary Indigenous scholarship in order to argue that a meaningful response to the climate crisis requires re-enchanted attachments to life that necessitate a departure from the onedimensional temporality of the mythologies of settler law.

Brenna Bhandar's contribution to this special issue is an exciting supplement to Peter's early work on race, class and law, for which she was able to access files given her by Peter from this period. These files contained a 'treasure trove' (Brenna's words) of notes, newspaper clippings, and correspondence between him and others on the drafts of his (1987) article, 'Racism and the Innocence of Law'. Using as a point of departure Fitzpatrick's foundational critique of liberal legality and racism, as outlined in his (1987) text, Bhandar considers the ways in which neoliberal legality is parasitic upon liberal legal racial formations while, at the same time, obscures the foundational place of race in contemporary capitalism by subsuming material life within its modes of value extraction.

Jackson Reese Faust explores Peter's intellectual relationship with French philosopher Jean-Luc Nancy in relation to the problems of myth and community. Working through the 'restlessness of the negative', which Nancy describes in Hegel, Faust performs a supplemental reading of Fitzpatrick's notion of 'law as resistance' in which there is 'always more to be done', affirming the necessity of some extra-formal legality - that is, the political — that must be opened through negativity.

In Kathleen Birrell's 'Convivial Mythologies: The Poiesis of Modern Law', she very poetically explores the poiesis of modern law through a consideration of the artifice of autopoiesis that grounds the mythology of law, and the fictive filaments by which this contrivance is archived and maintained, before engaging with Fitzpatrick's literary engagements, as subversive supplements to law, and the decolonial 
implications of his rendering of the 'constituent correspondence' between law and literature to consider the ways in which this intellectual legacy provides a compelling opening to the possibility of mythological plurality.

Erdem Ertürk and Anastasia Tataryn's contribution to the special issue aims to supplement Peter's reading of international law, as that which centres upon the idea of a generative force, or an event that renders international law both assuredly determinate and illimitably responsive. The authors test the response of international law to unrecognised 'states' within the context of Fitzpatrick's approach and they identify the continuing contemporary relevance of his reading of international law via two case studies exemplifying states caught in de facto recognition-as-unrecognised: North Cyprus and Crimea.

Finally, also in the area of international law, Roberto Vilchez Yamato argues that Fitzpatrick provides a unique contribution to international studies, most especially to contemporary interdisciplinary studies of International Law (IL) and International Relations (IR). Yamato's complex and Derridian-inspired engagement with and supplement to Peter's scholarship celebrates him not only as a critical thinker of modern law, but also as a critical thinker of the modern international. A fitting way to conclude the special issue.

We are grateful not only to the above contributors to this very special issue of Law and Critique for their willingness to reflect deeply, seriously and yet creatively on Peter's work, but to a range of other people besides. Our thanks go to the Editorial Committee of the journal for their assistance and advice, and for their help with peer review_and in particular to Fiona Macmillan and Emilios Christodoulidis. But it would be remiss of us to fail to mention and to celebrate the work of Valerie Kelley. Valerie has been instrumental to the work of Law and Critique since its early days and we were honoured (and lucky beyond words) to work with her on this, her last issue of the journal. Like Peter, her work and legacy will continue to inspire scholars. We hope you enjoy the special issue. It is, unsurprisingly, dedicated to the memory of an extraordinary intellectual, friend, and mentor. Vale Peter Fitzpatrick.

\section{References}

Fitzpatrick, Peter. 1980. Law and the state in Papua New Guinea. London: Academic Press.

Fitzpatrick, Peter. 1987. Racism and the innocence of law. Journal of Law and Society 14(1): 119-132.

Fitzpatrick, Peter, ed. 1991. Dangerous supplements: Resistance and renewal in jurisprudence. London: Pluto Press.

Fitzpatrick, Peter. 1992. The mythology of modern law. London: Routledge.

Fitzpatrick, Peter. 2001. Modernism and the grounds of law. Cambridge: Cambridge University Press.

Publisher's Note Springer Nature remains neutral with regard to jurisdictional claims in published maps and institutional affiliations. 